\title{
Pengembangan Organisasi Pemuda dan Olahraga cabang Wushu unit Jatinangor menjadi Organisasi Berprestasi yang Berwawasan Kesehatan dan Kewirausahaan
}

\author{
Muhammad Nur Abdillah'1, Eva Kusumahati², Anas Bunyamin ${ }^{3}$ \\ 1, 2 Sekolah Tinggi Farmasi Bandung, Indonesia, ${ }^{3}$ Universitas Padjadjaran, Indonesia
}

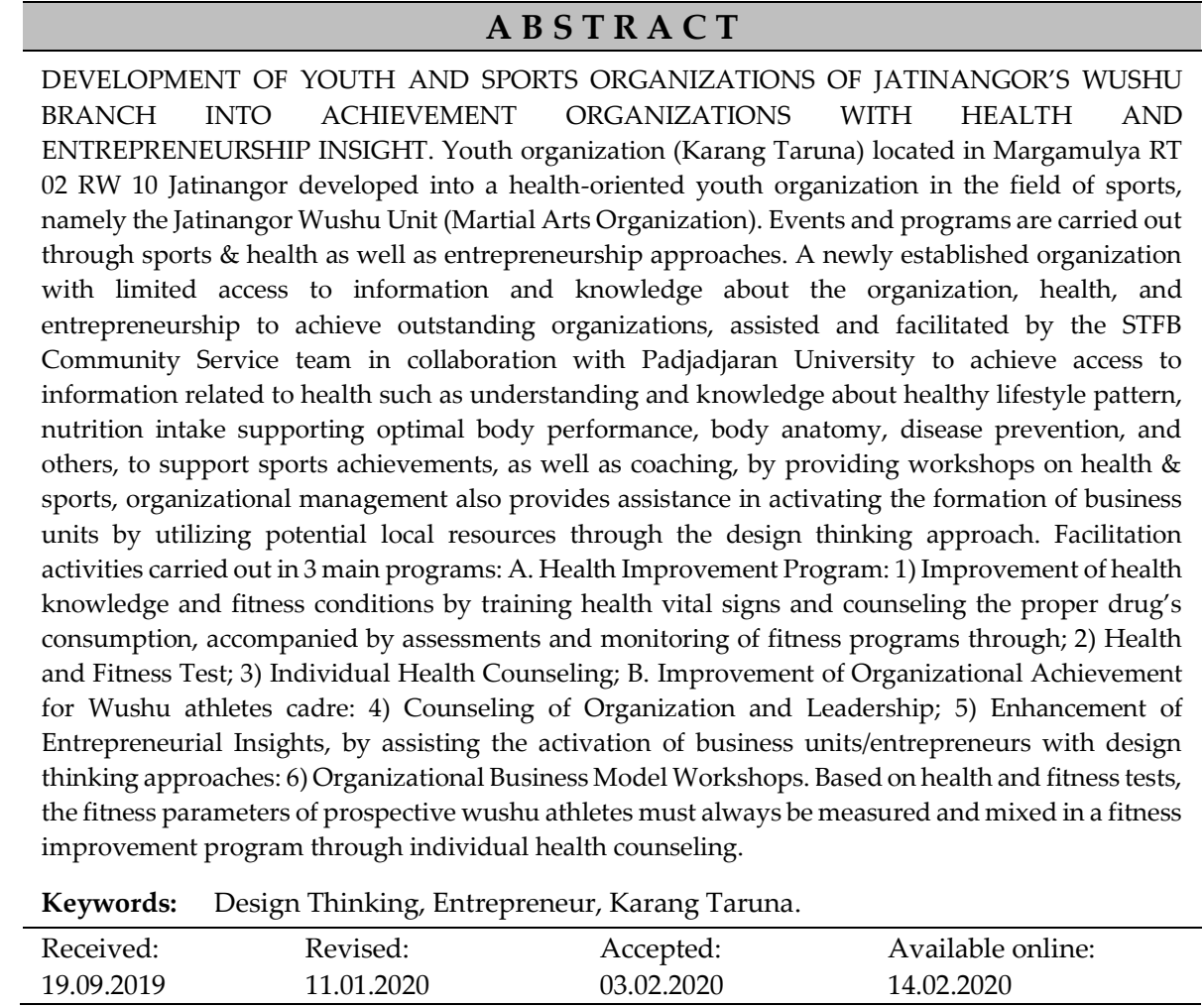

\section{Suggested citation:}

Abdillah, M., Kusumahati, E., \& Bunyamin, A. (2020). Pengembangan organisasi pemuda dan olahraga cabang wushu unit Jatinangor menjadi organisasi berprestasi yang berwawasan kesehatan dan kewirausahaan. Jurnal Pengabdian Pada Masyarakat, 5(1), 83-90. https://doi.org/10.30653/002.202051.245

Open Access I URL: http://ppm.ejournal.id/index.php/pengabdian/article/view/245

${ }^{1}$ Corresponding Author: Jl. Soekarno-Hatta No.754, Cipadung Kidul, Kec. Panyileukan, Kota Bandung, Jawa Barat 40614, Indonesia; Email: muhammad.nurabdillah@stfb.ac.id 


\section{PENDAHULUAN}

Karang taruna merupakan wadah pengembangan kemasyarakatan diharapkan dapat menjadi media pertumbuhan potensi, pembentukan karakter dan kemandirian, dan khususnya generasi muda. Karang Taruna yang berlokasi di Dusun Margamulya RT 02/RW 10 Kecamatan Jatinangor ini mempunyai semangat dan itikad baik untuk mengembangkan potensi generasi mudanya. Dinisiasi oleh salah satu pemuda lokal di daerah tersebut tercetus ide untuk melakukan kegiatan Karang taruna melalui pendekatan di bidang keolahragaan \& kesehatan juga kewirausahaaan, dengan cabang olah raga Wushu sebagai wadahnya. Sejauh ini, legal formal pembentukan cabang olahraga Wushu unit Jatinangor yang menginduk pada Cabang Wushu Sumedang dan sosialisasi mengenai kegiatan bidang olahraga kepada pemuda telah dilakukan, begitu juga perizinan sarana tempat latihan sedang dikomunikasikan dengan berbagai pihak, baik dengan warga setempat secara swadaya, ataupun dengan instansi yang mempuyai lahan memadai untuk dilakukannya kegiatan tersebut. Komunikasi dengan tim kepelatihan yang akan berkontribusi memberikan pembinaan dan pemberdayaan, dan pengembangan diri telah dijalin dengan pihak profesional yang berkompeten di bawah binaan KONI Sumedang. Kegiatan ini diharapkan dapat membentuk fisik dan jiwa yang sehat, penggalian potensi dan pembinaan bibit-bibit atlet berbakat yang berprestasi, pembentukan pemuda yang berkarakter, berkualitas dengan mewujudkan pemuda yang memiliki rasa nasionalisme tinggi, juga terampil, cerdas, inovatif, serta kesadaran dan tanggung jawab sosial, disertai kemandirian dan jiwa kewirausahaan melalui aktivasi unit usaha yang mengangkat potensi-potensi lokal.

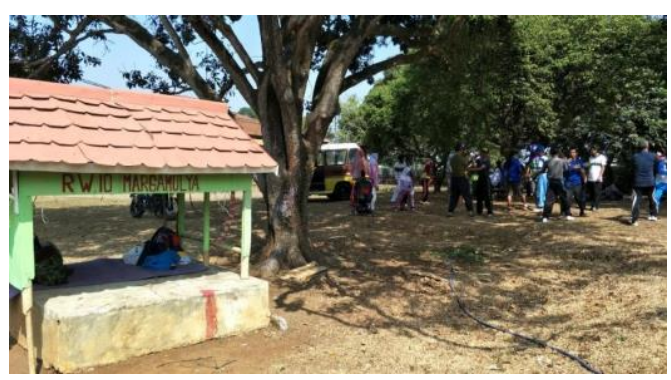

Gambar 1. Lapangan RW 10 Margamulya Tempat Berkegiatan

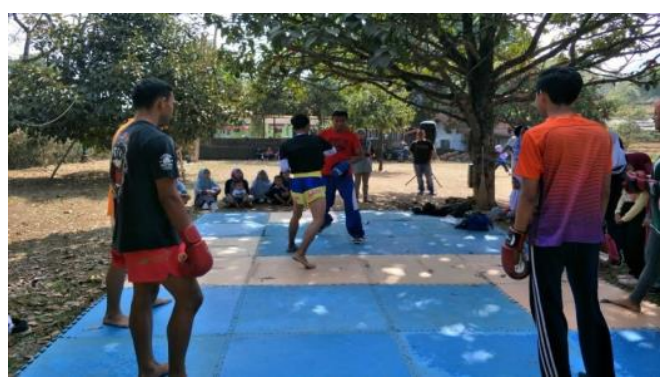

Gambar 2. Kegiatan Latihan Olahraga Wushu

Sebagai organisasi yang baru terbentuk, terdapat beberapa keterbatasan dalam mengembangkan organisasi yang baik seperti: keterbatasan kemampuan dan pemahaman mengenai managemen keorganisasian yang baik, keterbatasan akses 
informasi dan teknologi mengenai keolahragaan yang erat berkaitan dengan kesehatan seperti pemahaman dan pengetahuan tentang ritme dan pola hidup sehat, asupan nutrisi penunjang kinerja tubuh optimal, anatomi tubuh, pencegahan penyakit, dll., untuk menopang prestasi olahraga, serta keterbatasan pengetahuan dan skill dalam membangun dan mewujudkan unit usaha terutama bagi pemuda karang taruna atau unit wushu yang dapat menjadi modal kemandirian organisasi dalam mewujudkan sarana latihan yang baik secara swadaya. Tim Pengabdian Masyarakat STFB yang berkolaborasi dengan Universitas Padjadjaran dapat memfasilitasi serta membantu pencapaian akses informasi berkaitan dengan kesehatan seperti pemahaman dan pengetahuan tentang ritme dan pola hidup sehat, asupan nutrisi penunjang kinerja tubuh optimal, anatomi tubuh, pencegahan penyakit, dll., untuk menopang prestasi olahraga, serta kepelatihan, dengan memberikan workshop mengenai aspek kesehatan \& keolahragaan, managemen keorganisasian juga memberikan pendampingan aktivasi pembentukan unit usaha dengan melihat/memanfaatkan potensi lokal melalui pendekatan design thinking.

Pemahaman mengenai ritme kerja tubuh harian memungkinkan pemuda usia produktif muda terhindar dari pola hidup dan ritme kerja tubuh harian yang dapat memicu stress oksidatif yang membuat tubuh sangat rentan terhadap risiko kerja tubuh yang menurun dengan cepat bahkan sebelum usia produktif berakhir (Thun, Bjorvatn, Flo, Harris, \& Pallesen, 2015). Pola hidup yang tidak sehat dari ritme kerja tubuh harian yang berlebihan serta asupan nutrisi baik yang kurang dapat mempengaruhi kerja tubuh yang tidak optimal serta dapat mengurangi produktivitas jangka panjang masyarakat dan memicu kerentanan terhadap penyakit degeneratif pada usia lanjut (Fullagar et al, 2015; Volek, Noakes, \& Phinney, 2015). Tingkat pemahaman yang kurang serta informasi pola hidup sehat yang belum tersampaikan secara individu dan personal, membuat usia produktif ini cenderung tidak peduli dan mengabaikan risiko tersebut (Close, Hamilton, Philp, Burke, \& Morton, 2016; Giriwijoyo \& Sidik, 2012). Dalam disiplin cabang olahraga Wushu, diasah kemampuan mengolah pernafasan, pengetahuan untuk memahami anatomi tubuh kita, dan juga mempelajari ramuan tradisional serta asupan nutrisi yang baik untuk memperkuat tubuh untuk sebagai penopang prestasi olahraga dengan kinerja tubuh yang optimal, serta pendalaman karakter disiplin untuk mengatur pola hidup dan ritme kerja tubuh harian yang baik (Yuanghai, Yizhi, Mung, \& Xiwen, 2017).

Konseling merupakan salah satu cara untuk menggali data atlet binaan yang menjadi sasaran kegiatan, sehingga dari data yang diperoleh, dapat dilakukan analisis untuk memberikan solusi individual dan personal kepada warga sasaran agar meningkatkan pengetahuan serta pemahaman atas ritme kerja, pola hidup, dan asupan nutrisi yang baik yang mempengaruhi kerja tubuh yang optimal sehingga diharapkan dapat menimbulkan kesadaran untuk mengubah perlahan hal-hal yang dapat memicu kerja tubuh yang tidak optimal dan menerapkannya serta menularkannya kepada keluarga dan masyarakat sekitar. Usia produktif yang sadar akan kerja tubuh optimal akan menunjang kerja produktif lebih baik untuk peningkatan kualitas kehidupan (Andriani \& Wijatmadi, 2012).

Organisasi yang terdiri dari beberapa orang dengan berbagai macam latar belakang keahlian merupakan salah satu dari empat elemen utama dalam teknologi yang harus 
dikuasai selain keteknikan, manusia dan manajemen informasi (UNESCAP, 1989). Uniknya, seringkali porsi penguasaan keorganisasian dianggap paling tidak penting dibandingkan dengan ketiga elemen lainnya. Padahal, beberapa kasus menunjukkan bahwa penguasaan teknologi, SDM dan informasi seringkali gagal dalam penerapannya dikarenakan faktor organisasi tidak ditangani dengan benar (Purnomo \& Kurniawan, 2017).

Karang Taruna merupakan organisasi kemasyarakatan berbasis elemen kepemudaan yang berpotensi untuk dikembangkan sebagai model pemeran The Local Enablers (TLE). TLE merupakan pemberdaya lokal yang berfungsi untuk mengelevasi kemajuan di masyarakat dengan berpegang teguh pada nilai-nilai lokal, komoditas lokal, masyarakat lokal dan potensi-potensi lokal lainnya (Bunyamin, Purnomo, Taofik, \& Nawawi, 2016). Penerapan konsep TLE lebih kepada peningkatan kemajuan masyarakat yang diawali dengan pembelajaran konsep berpikir maju, ideasi mengenai komoditas/produk unggulan lokal yang akan menjadi target titik kolaborasi, serta penjejaringan masyarakat lokal dengan penghubung dan masyarakat perkotaan sebagai kolaborator untuk pemasaran produk (Bunyamin \& Purnomo, 2017). Konsep pengembangan Karang Taruna sangat mirip dengan konsep pengembangan TLE yang berbasis komunitas. Keunggulan dari model organisasi pemberdayaan berbasis komunitas adalah adanya motif yang hampir sama dari setiap partisipan untuk berperan dalam kegiatan komunitas.

\section{METODE}

Tim Pengabdian Masyarakat STFB yang berkolaborasi dengan Universitas Padjadjaran melaksanakan program yang dapat memfasilitasi pengurus organisasi mengatasi keterbatasan yang ada, seperti:

1) Membantu pencapaian akses informasi berkaitan dengan kesehatan seperti pemahaman dan pengetahuan tentang ritme dan pola hidup sehat, asupan nutrisi penunjang kinerja tubuh optimal, anatomi tubuh, pencegahan penyakit, dll., untuk menopang prestasi olahraga, serta kepelatihan;

2) Memberikan workshop mengenai aspek kesehatan \& keolahragaan, managemen keorganisasian, dan kepelatihan;

3) Memberikan pendampingan aktivasi pembentukan unit usaha dengan melihat/memanfaatkan potensi lokal melalui pendekatan design thinking;

4) Konseling individual dan personal terhadap kader kesehatan dalam organisasi serta atlet binaan mengenai pemahaman atas ritme kerja tubuh harian, pola hidup, dan asupan nutrisi yang baik yang mempengaruhi kerja tubuh yang optimal sebagai penopang prestasi olahraga.

\section{HASIL DAN PEMBAHASAN}

\section{Tes Kesehatan dan Kebugaran}

Pemeriksaan kesehatan dilakukan oleh dokter dengan melakukan anamnase, pemeriksaan fisik, denyut jantung, paru-paru, kesehatan tenggorokan, mata dan 
kelenturan tungkai gerak. Selanjutnya diberikan rujukan tes lanjutan, yaitu tes urin untuk melihat kesehatan hati, ginjal dan kemungkinan penyalahgunaan obat di laboratorium klinik Prodia Kota Bandung.

Pemeriksaan kesehatan dan kebugaran merupakan langkah awal asesmen tingkat kesehatan dan kebugaran atlet untuk menunjang program kegiatan selanjutnya. Pemeriksaan kesehatan juga dilakukan untuk memberikan rujukan tes selanjutnya agar diperoleh data parameter kesehatan dan kebugaran yang baik. Pemeriksaan kesehatan dilakukan oleh dokter dibantu mahasiswa dan tes lanjutan yang dilakukan adalah tes urin di laboratorium klinik Prodia Kota Bandung.

\section{Pelatihan dan Penyuluhan Kesehatan}

Kegiatan pelatihan dan penyuluhan berguna untuk meningkatkan wawasan kesehatan dasar dari para kader calon atlet wushu yang menunjang kemampuan kader pelakukan asesmen keadaan kegawatdaruratan pada saat melakukan kegiatan latihan atau olahraga untuk menghindari cidera dan kemalangan, wawasan perhitungan tingkat kebugaran serta wawasan penggunaan obat yang benar melalui pendekatan DAGUSIBU.

Kegiatan pelatihan dan penyuluhan berguna untuk meningkatkan wawasan kesehatan dasar dari para kader calon atlet wushu. Wawasan kesehatan dasar yang diberikan berupa: 1) pelatihan tanda-tanda vital kesehatan yang menunjang kemampuan kader pelakukan asesmen keadaan kegawatdaruratan pada saat melakukan kegiatan latihan atau olahraga untuk menghindari cidera dan kemalangan; 2) pelatihan perhitungan tingkat kebugaran;3) penyuluhan wawasan penggunaan obat yang benar melalui pendekatan DAGUSIBU.

Pelatihan 1 dan 2 diberikan oleh pemateri Perawat dan Dosen dari Stikes Dharma Husada Bandung, Ibu Erlina, M.Kes. Ners., sedangkan penyuluhan DAGUSIBU diberikan oleh pemateri dari pelaksana, Muhammad Nur Abdillah, M.Si., Apt., dan Eva Kusumahati, M.Si., Apt., serta dibantu oleh mahasiswa STFB.

\section{Konseling Individual}

Konseling individual dan personal terkait peningkatan wawasan kesehatan kader calon atlet binaan mengenai pemahaman atas ritme kerja tubuh harian, pola hidup, dan asupan nutrisi yang baik yang mempengaruhi kerja tubuh yang optimal sebagai penopang prestasi olahraga, serta peningkatan kapasitas organisasi, potensi kepemimpinan dan wawasan kewirausahaan.

Konseling merupakan salah satu cara untuk menggali data kader calon atlet binaan yang menjadi sasaran kegiatan, sehingga dari data yang diperoleh, dapat dilakukan analisis untuk memberikan solusi individual dan personal yang dapat menambah wawasan kepada kader calon atlet wushu.

\section{Konseling Kesehatan dan Kebugaran}

Konseling kesehatan dan kebugaran bertujuan meningkatkan pengetahuan serta pemahaman atas ritme kerja, pola hidup, dan asupan nutrisi yang baik yang mempengaruhi kerja tubuh yang optimal sehingga diharapkan dapat menimbulkan kesadaran untuk mengubah perlahan hal-hal yang dapat memicu kerja tubuh yang tidak optimal dan menerapkannya serta menularkannya kepada keluarga dan 
masyarakat sekitar. Kader calon atlet wushu yang sadar akan kerja tubuh optimal akan menunjang kerja produktif lebih baik untuk peningkatan kualitas kehidupan dan menunjang program atlet berprestasi untuk target kejuaraan. Konselor utama adalah dari pelaksana kegiatan, Muhammad Nur Abdillah, M.Si., Apt. Data asesmen kesehatan dan kebugaran diolah oleh mahasiswa STFB.

\section{Konseling Organisasi, Kepemimpinan dan Kewirausahaan}

Seperti konseling kesehatan dan kebugaran di atas, konseling organisasi, kepemimpinan dan kewirausahaan juga dapat meningkatkan pemahaman kader calon atlet wushu akan potensi diri dan lingkungan yang dapat membentuk kepribadian yang berprestasi dan unggul. Selain peningkatan wawasan para kader, konseling ini juga berguna untuk asesmen awal pembinaan kader dari data potensi individu kader untuk dapat berperan dalam menggerakkan organisasi ke depan. Konselor utama adalah dari pelaksana kegiatan, Muhammad Nur Abdillah, M.Si., Apt., dan Anas Bunyamin, S.TP., M.Si.

\section{Kaderisasi}

Kaderisasi dilakukan dengan pendampingan dan pembinaan harian untuk para kader calin atlet melaksanakan program yang telah dirumuskan dari asesmen konseling individual. Kaderisasi merupakan kegiatan pendampingan dan pembinaan harian yang dilakukan dengan memberikan program yang harus dijalani oleh kader calon atlet wushu berdasarkan asesmen kesehatan, kebugaran, potensi organisasi, kepemimpinan dan kewirausahaan. Program yang dijalankan akan dimonitor dan dievaluasi secara berkala per 2 pekan dan diukur parameter capaian untuk melihat progres target yang diharapkan. Pemantau kaderisasi utama adalah pelaksana, Muhammad Nur Abdillah, M.Si., Apt.

\section{Lokakarya Design Thinking}

Proses lokakarya merujuk pada runutan perumusan ide-ide inovatif, kreatif dan solutif untuk menjawab permasalahan mendasar yang menjadi kendala pengembangan kapasitas organisasi, melalui tahapan proses observasi, perumusan masalah, memunculkan ide dan solusi inovatif dan kreatif, merumuskan program kerja organisasi dan melakukan evaluasi kinerja program kerja.

Pendekatan Design Thinking dilakukan dalam menyelenggarakan Lokakarya Keorganisasian dan Wawasan Kewirausahaan untuk para kader calon atlet wushu. Proses lokakarya merujuk pada runutan perumusan ide-ide inovatif, kreatif dan solutif untuk menjawab permasalahan mendasar yang menjadi kendala pengembangan kapasitas organisasi.

Perumusan ide diawali dengan observasi potensi diri masing-masing kader, potensi keorganisasian, potensi kepemimpinan dan potensi dari pengaruh lingkungan sekitar, dari proses observasi dapat dicapai suatu rumusan peran dari masing-masing individu kader dalam organisasi yang dituangkan dalam bentuk Struktur Organisasi dan Tata Kelola (SOTK) beserta deskripsi tanggung jawab, peran dan Key Performance Indicator (KPI) masing-masing kader.

Dalam langkah menyusun suatu program kerja tahunan organisasi, diawali dengan perumusan visi dan misi dengan pendekatan Design Thinking, dilanjutkan dengan 
perumusan langkah-langkah utama kegiatan, pilar pengembangan organisasi dan rencana aksi pada pilar pengembangan program sesuai target terukur yang ingin dicapai.

Kegiatan Lokakarya dilakukan dalam dua hari pelatihan semi bootcamp, dengan dipandu oleh pelaksana utama, Muhammad Nur Abdillah, M.Si., Apt., dan Anas Bunyamin, S.TP., M.Si., dengan dibantu fasilitator dari Sacita Muda dan Komunitas The Local Enablers.

\section{Studi Banding ke The Local Enablers}

Komunitas kreatif The Local Enablers merupakan komunitas kewirausahaan sosial yang sukses mewadahi UMKM/UKM lokal di wilayah Jatinangor, dengan start-up unggulan yang berprestasi sebagai motor penggeraknya yaitu Sacita Muda. Sacita Muda mencerminkan organisasi berprestasi yang berwawasan kewirausahaan yang dapat dicontoh sebagai role model pengembangan kapasitas kader komunitas Puragasedaya dari organisasi wushu, sehingga para kader ditugaskan untuk studi banding ke sana, dan diberikan suatu tugas studi kasus untuk dipelajari dan didalami selama studi banding berlangsung.

\section{Monitoring Hasil Program Kebugaran}

Setiap kader calon atlet diberikan panduan program kebugaran berupa program latihan harian, mingguan dan sesuai target kejuaraan, berikut panduan nutrisi asupannya secara personal. Kader diwajibkan mengikuti panduan program dan akan dimonitor kebugarannya sesuai target yang ditetapkan selama 3 pekan hingga 3 bulan.

\section{Evaluasi Program Kerja dan Model Bisnis}

Program kerja yang telah dirumuskan pada lokakarya SOTK, Visi dan Misi, serta Program Kerja, akan ditugaskan kepada kader untuk dapat dilaksanakan secara mandiri untuk periode 2-3 bulan. Evaluasi pelaksanaan program kerja yang dirumuskan dilakukan bersama tim pelaksana dalam bentuk asesmen lapangan. Evaluasi model bisnis dilakukan dengan menganalisa cash-flow dari revenue yang diperoleh dari kegiatan/program kerja organisasi yang ditugaskan pada periode 2-3 bulan.

\section{SIMPULAN}

Peningkatan pengetahuan kesehatan dan kondisi kebugaran dapat dilakukan dengan pelatihan tanda-tanda vital kesehatan dan penyuluhan penggunaan obat yang benar. Berdasarkan tes kesehatan dan kebugaran, maka parameter kebugaran kader calon atlet wushu harus selalu terukur dan diramu dalam suatu program peningkatan kebugaran melalui konseling kesehatan individual. Berdasarkan konseling kesehatan individual, maka aderisasi organisasi berprestasi dilakukan dengan konseling organisasi, kepemimpingan dan wawasan kewirausahaan, sehingga menunjukkan kebutuhan peningkatan kapasitas organisasi dan wawasan kewirausahaan dalam bentuk lokakarya. Lokakarya Design Thinking dilakukan berupa penyusunan SOTK, perumusan visi dan misi serta program kerja tahunan organisasi, serta perumusan 
Model Bisnis Organisasi berwawasan kewirausahaan. Studi banding kepada komunitas kreatif dilakukan seiring dengan evaluasi pemantauan program kebugaran, organisasi dan penerapan bisnis model.

\section{REFERENSI}

Andriani, M., \& Wijatmadi, B. (2012). Pengantar gizi masyarakat. Jakarta: Kencana Prenada Media Group.

Bunyamin, A. dan Purnomo, D. (2017). Entrepreuner speak up!: Kumpulan paper pengembangan enterpreneurship untuk perguruan tinggi. Bandung: Bitread Publishing.

Bunyamin, A., Purnomo, D., Taofik, S., \& Nawawi, M. (2016). The local enablers: Mengusung pemberdaya lokal berorientasi global dalam kerangka bisnis sosial. Konferensi Nasional Inovasi dan Technopreneurship, 32-37.

Close, G. L., Hamilton, D. L., Philp, A., Burke, L. M., \& Morton, J. P. (2016). New strategies in sport nutrition to increase exercise performance. Free Radical Biology and Medicine, 98, $144-158$.

Fullagar, H. H., Duffield, R., Skorski, S., Coutts, A. J., Julian, R., \& Meyer, T. (2015). Sleep and recovery in team sport: Current sleep-related issues facing professional team-sport athletes. International Journal of Sports Physiology and Performance, 10(8), 950-957.

Giriwijoyo, S., \& Sidik, D. Z. (2012). Ilmu kesehatan olahraga. Bandung: Remaja Rosdakarya.

Purnomo, D., \& Kurniawan, K. I. A. (2017). Sociopreneur milienial: Bisnis berbasis kolaborasi antara desa dan kota. Bandung: Bitread Publishing.

Thun, E., Bjorvatn, B., Flo, E., Harris, A., \& Pallesen, S. (2015). Sleep, circadian rhythms, and athletic performance. Sleep Medicine Reviews, 23, 1-9.

United Nations Economic and Social Commission for Asia and the Pasific [UNESCAP]. (1989). Technology atlas project: a Framework for technology-based development, Volume 2-6, Bengalore: APCTT.

Volek, J. S., Noakes, T., \& Phinney, S. D. (2015). Rethinking fat as a fuel for endurance exercise. European Journal of Sport Science, 15(1), 13-20.

Yuanghai, G., Yizhi, W., Mung, G., \& Xiwen, L. (2017). Analysis of application of core strength training in competitive wushu routing excercise. International Symposium of Social Science Management and Innovation.

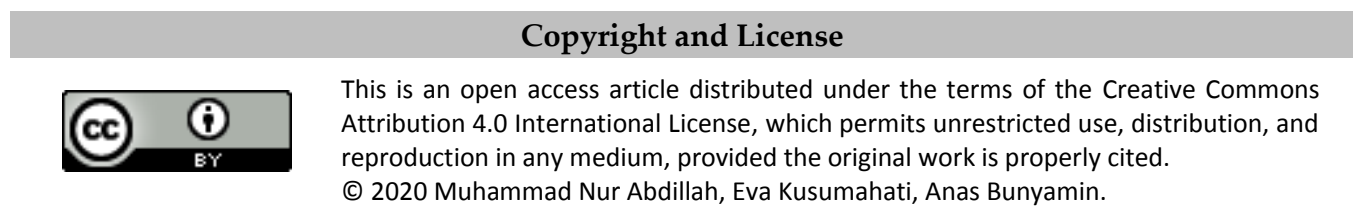

Published by LP3M of Universitas Mathla'ul Anwar Banten in collaboration with the Asosiasi Jurnal Pengabdian Kepada Masyarakat (AJPKM) 